\title{
Macroecenomic identification of the pricing factors on the Johannesburg Stock Exchange
}

\author{
G.D.I. Barr \\ Department of Mathematical Statistics and Economics, University of Cape Town, Rondebosch, 7700 Republic of South Africa
}

Accepted 1 March 1989

\begin{abstract}
This paper considers the main economic forces which drive the various sectors of the Johannesburg Stock Exchange, over the period 1979-1987. A factor-analysis approach identified these main forces as the price of gold, the short-term rate of interest, the performance of foreign stock markets, and local business confidence. The period considered is broken down into several subperiods in which these economic factors performed differently and where one or other dominated. This enables one to obtain a precise idea of which economic
\end{abstract} variables move which sectors and when.

Hierdie artikel oorweeg die hoof ekonomiese kragte wat die verskillende sektore van die Johannesburgse Effektebeurs oor die tydperk 1979-1987 aangedryf het. Deur gebruik van 'n faktoranalisebenadering kon hierdie hoofkragte as die prys van goud, die korttermynrentekoers, die vertoning van buitelandse effektebeurse en die plaaslike besigheidsvertroue identifiseer word. Die period wat in ag geneem is is in verskeie subperiodes afgebreek waarin hierdic ekonomiese faktore verskillend vertoon het, en waar die een of ander gedomineer het. Dié benadering gee 'n presiese idee van watter ekonomiese veranderlikes die verskillende sektore aandryf, en wanneer.

\section{Introduction}

Since its inception in the mid-sixties the Sharpe-Lintner CAPM (Capital Asset Pricing Model) has formed the basis for empirical and theoretical research in the area of portfolio analysis. In the seventies, however, several studies took issue with the general applicability of the CAPM, culminating in the Roll critique (Roll, 1977). In 1976, Ross proposed the APT (Arbitrage Pricing Theory) as an alternative paradigm to the CAPM. The APT represents a generalization of the CAPM in which compensation for bearing risk is decomposed into various risk premiums in contrast to the single risk premium of the CAPM. The original empirical investigation of the APT model was undertaken by Roll \& Ross (1980) on the NYSE (New York Stock Exchange) in which these risk premia are estimated as orthogonal factors. This study, along with that of Cho (1984) provided support for the theory.

South African research on the theory is limited to that done by Page (1986) who applied Roll \& Ross's technique to the JSE (Johannesburg Stock Exchange) and Meyer (1986), who tested the applicability of the APT to commodity pricing. Page concluded, that work on the actual identification of the estimated factors in the APT model had to be done before the APT could be seen as a normative theory. However, he was able to establish that two dominant pricing factors existed on the JSE.

Work on this problem of factor identification has been done in the USA (Roll, Ross \& Chen, 1986) and in the UK (Beenstock \& Chan, 1988), but no published work has as yet considered factor identification on the JSE. In this paper the author considers the problem of factor identification for the APT by using graphical singular value decomposition techniques for the non-gold sector of the JSE. Gold shares were excluded as their movement would quite clearly be dominated by movements in the gold price. The variability of returns on non-gold indices on the JSE is divided into two dominant factors. A range of macroeconomic variables are then plotted in the space of these two factors in order to identify the macroeconomic variables relating most clearly to the factors. Most importantly, the technique allows one to examine the relative importance of factor 1 as against factor 2 (and hence their associated economic forces) in driving the market at different points in time.

\section{The APT}

\section{Developmemt of the theory}

In 1964 the Sharpe-Lintner CAPM was introduced to the Investment fraternity as a single index market model. The CAPM assumes that investors are only concerned with portfolio risk and expected returns and concludes that the expected return on a security is linearly related to the returns on the market in the following way:

$E\left(R_{i}\right)=R_{f}+\beta\left[E\left(R_{m}\right)-R_{f}\right]$

where $E\left(R_{i}\right)=$ the expected return on security $i$; $E\left(R_{m}\right)$ $=$ the expected return on the market; $R_{f}=$ the risk-free rate (usually the treasury bill rate); and $\beta_{1}=$ covariance $\left(R_{i} ; R_{m}\right) /$ variance $\left(R_{m}\right)$.

Over the years, however, the empirical analysis of the CAPH high-lighted the shortcomings of the model Firstly, studies on the NYSE found a systematic ex post dependence in the residuals (Ageon \& Lessard, 1977; Basu, 1975; and Farrel, 1975). Secondly, average returns of securities were inversely related to the size of the firm (Banz, 1981 and Reinganum, 1981).

Despite these anomalies revealed in the empirical research, the CAPM has never been satisfactorily tested due to the lack of a true market portfolio. Roll (1977) argued that unless the market portfolio could be accurately observed, a test of the CAPM using ex post 
data would only be a test of the proxy portfolio.

Empirical research on the JSE has failed to identify similar anomalies. In the definitive study by Bradfield (1988), the CAPM was found to be a reasonable model for the JSE; there was no dividend yield effect, no size or market capitalization effect nor a liquidity effect.

In 1976 Ross introduced the APT as an alternative to the CAPM. Whereas the CAPM has a risk premium related to the market portfolio, the $A P T$ has various risk premia related to the macroeconomic variables that affect the pricing of securities. Thus, the market portfolio has no explicit role to play in the APT. The returns of securities can thus be expressed in terms of a $k$ factor model:

$R_{i}=E_{i}+\beta_{i 1} F_{1}+\beta_{i 2} F_{2}+\ldots+\beta_{i k} F_{k}+e_{i}$

where $R_{i}$ is the random rate of return on the $i$ th security, $i=1.2,3, \ldots, n ; E_{i}$ is the expected return on the $i$ th security, $i=1,2,3, . ., n ; F_{j}$ is the $j$ th common factor which influences the returns on all assets, $j=1,2,3, \ldots, k ; \beta_{i j}$ is the sensitivity of security $i$ to movements in the common factor $j$; and $e_{i}$ is the return on the unsystematic idiosyncratic factors

for security $i$.

The $k$ factor model operates in an environment governed by the following three assumptions:

1. capital markets are perfectly competitive;

2. investors are risk averse and always prefer more wealth to less wealth; and

3. individuals have homogeneous beliefs that asset returns can be represented by a linear $k$ factor model of the form given in (1.2).

The empirical analysis of the APT has focused on the identification of $k$ and the identification of the factors, $F_{j}$ for $j=1,2,3, . . k$.

\section{Establishment of $k$}

Roll \& Ross (1980) followed a two-step procedure in establishing the number of factors on the NYSE. Firstly, the returns of 42 portfolios of 30 securities were factor analysed using Maximum Likelihood

Factor Analysis (MLFA) and then the factor loadings were regressed on the expected returns of the portfolios. Based on the significance of the $t$ tests of the regression coefficients the number of factors significant in the pricing of the securities was established. Roll \& Ross established that at least three, and probably four, factors were present in the returns generating process.

However, the Roll \& Ross methodology was severely criticized by Shanken (1982) and Dhrymes, Friend \& Gultekin (1984). Shanken questioned the use of factor analysis as it cannot identify the unique factor structure of the returns. Furthermore, he argued that in order to test the APT the universe of securities in which the APT is assumed to operate must be factor analysed and not simply the portfolios of securities. Dhrymes et al. (1984) found that there was a positive dependency between the number of securities factor analysed and the number of factors identified.
Dhrymes et al. (1984) also took issue with the second step of the Roll \& Ross methodology and proposed a generalized least squares framework for establishing the number of priced factors. This method takes into account the positive dependency that exists between the security returns, factor loadings, and standard deviations of the returns which are induced by the positive skewness of the returns.

In 1988, Conway \& Reinganum used MLFA along with cross-validation and established the existence of one major factor and one minor factor. Furthermore, there was no positive dependency between the number of securities factor analysed and the number of factors established when this technique was used.

Page (1986) applied the Roll \& Ross methodology to the JSE and established the existence of two dominant factors. The APT was also tested as an alternative to the CAPM and was found to be substantially better in explaining the variability of returns.

Identification of the $k$ factors in terms of macroeconomic variables

Roll, Ross \& Chen (1986) and Beenstook \& Chan (1988) both identified four factors in terms of macroeconomic variables on the NYSE and LSE, respectively, although they used somewhat different methodologies (Table 1).

Roll, Ross \& Chen identified candidate macroeconamic variables by considering the present value of security prices at the discounted value of expected dividends. Once these macroeconomic variables were selected, five factors were extracted from a portfolio of securities and a version of the FamaMacBeth (1973) technique was employed. Beenstook \& Chan set out to develop an alternative methodology which avoids the use of factor analysis and the anonymity of the market risk factors. Their approach rests on the specification of an economic model as the generating process of asset returns and used an iterative procedure to estimate the parameters in the model.

This paper serves to fill the gap in the research of the APT on the JSE. Based on the identification of the number of systematic factors affecting securities on the JSE by Page (1986) and the paper by Conway \& Reinganum (1988), it is attempted to only identify the first two factors in the APT model. The methodology is similar to that of Roll, Ross \& Chens in that the estimates of two factors are first obtained and it is then attempted to identify them. However, a biplot graphical

Table 1 The four macroeconamic variables identified on the NYSE and LSE as being associated with the four factors

\begin{tabular}{ll}
\hline \multicolumn{1}{c}{ NYSE } & \multicolumn{1}{c}{ LSE } \\
\hline 1. Industrial production & 1. Interest rates \\
2. Changes in the risk premium & 2. Fuel and material costs \\
3. Twists in the yield curve & 3. The money supply \\
4. Inflation & 4. Inflation \\
\hline
\end{tabular}


display will be used which uses a singular value decomposition to identify the factors, instead of the Fama-MacBeth technique.

\section{Methodology}

\section{Mathematical procedure}

\section{The Covariance Biplot}

The biplot was devised by Gabriel $(1971 ; 1972 ; 1981)$ and the extensive literature on the subject has been reviewed by Greenacre \& Underhill (1982) and Greenacre (1984). For a simple example of the application of the biplot to the JSE, readers are referred to Barr \& Affleck-Graves (1987).

The Covariance Biplot is a member of the singular value decomposition display procedure which plots the $m$ column points (variables) and $n$ row points (observations) of an $n \times m$ data matrix in a lower (usually two) dimenaionsal space. The singular value decomposition of a column-centred matrix $Y$ is computed to yield:

$$
Y=U D_{a} V^{T}
$$

where $D_{a}=\operatorname{diag}\left(a_{1}, a_{2}, \ldots a_{m}\right)$ with $a_{1} \geqslant a_{2} \geqslant a_{3} \ldots \geqslant a_{m}>0 ; m$ $=\operatorname{rank}(Y)$.

The rows of the $n \times m$ matrix, $F=U$, and the $m=m$ matrix $G=V D_{a}$ yield the coordinates for the graphical display of the rows and columns respectively. The interpretation of the biplot is in terms of distances of the points from the origin (or lengths) and the cosine of the angles that pairs of points subtend at the origin (angles between two points). The features of the Covariance Biplot that will be used in the analysis are listed below. 1. The quality of the biplot display in $p$ dimensions is given by

$$
q_{p}=\sum_{i=1}^{p} a_{i}^{2} / \sum_{i=1}^{m} a_{i}^{2}
$$

2. Since the length of the $i$ th row point multiplied by the length of the $j$ th column point and the cosine of the angle between them is an approximation of the element in row $i$ and column $j$ of the data matrix, row points which plot in the same half-plane as a particular column point have values which are above the mean of the column variable. Row points which lie in the opposite half plane have values which are below the mean of that column variable while row points which lie along a line at right angles to the line from the origin to the column point have values approximately equal to the mean of that column variable.

3. The length of the column points approximate the standard deviation of the variables. Thus, the more volatile a column variable, the further from the origin it will be plotted.

4. The cosine of the angle between the column points is an approximation to the correlation between the respective variables. Thus, positively correlated variables will lie in the same direction from the origin, negatively correlated variables will lie in the opposite direction from the origin, and uncorrelated variables will lie at right angles to each other.

The relative strength concept can be used in the graphical analysis of the biplot by combining two features of the biplot. If the variables in the data matrix are time series, the $n$ row points in the matrix $F$ also form a time series. Combining this property with the second feature discussed above, the movement of the row points over time can be interpreted as the relative strength of the individual column variables (see Barr \& AffleckGraves, 1987).

In our analysis the data matrix will have two column variables corresponding to the two dominant factors calculated for the JSE. The existence of two dominant factors is in line with published work an the JSE (Page, 1986) and the NYSE (Conway \& Reinganum, 1988). Thus the quality of the display in two dimensions will always be $100 \%$. The macroeconomic variables will then be plotted in the same space as the factors and the relative strength interpretation will be used to examine how the relationship between the two dominant factors and the macroeconamic variables has shifted over time.

\section{Factor analysis}

This technique allows us to compress a large set of correlated variables into a smaller set of principal components or factors which are mutually orthogonal and explain a significant proportion of the variability of the original set of variables. The factors of the APT model are the principal components of the space of security returns. In order to circumvent the problem of thin trading and allow a manageable set of data to be analysed, the returns on the 26 non-gold indices (rather than security returns) were decomposed into orthogonal factors. Since Page (1986) pointed to the existence of two priced factors the analysis will be confined to the identification of the first two factors.

Each factor can be expressed as a linear combination of the variables

$$
F_{i}=\sum_{j=1}^{26} a_{j i} R_{j} i=1,2, \ldots p
$$

where $F_{i}$ is the $i$ th factor, $a_{i j}$ is the coefficient of the $j$ th index return for the $i$ th factor, and $R_{j}$ is the time series of returns for the $j$ th index.

One may, as an alternative representation, express the returns in terms of the factors:

$R_{j}=\sum_{i=1}^{p} b_{j i} F_{i} j=1,2, \ldots 26$

In this representation the $b_{j i}$ are known as the factor loadings on factor $F_{i}$ for the index return $R_{j}$.

The decomposition of the index return space generally involves the rotation of the estimated factors so that the factor loadings are either very large or very small ( 0 or 1 
Table 2 The five most important indices in each factor according to the rotated factor loadings (August 1979-July 1987)

\begin{tabular}{ll}
\hline \multicolumn{1}{c}{ Factor 1 } & \multicolumn{1}{c}{ Factor 2 } \\
\hline 1. Transport & 1. Insurance \\
2. Clothing. footwear \& text & 2. Banks \& other \\
3. Sugar & 3. Building \& construction \\
4. Beverage. hotels \& leisure & 4. Tobacco \& match \\
5. Fumiture \& household & 5. Property trusts \\
\hline
\end{tabular}

under the scheme where the variables are standardized). The procedure used in order to perform this is known as the Varimax rotation (see Harman, 1976).

The actual estimates of the factors through time are known as the factor scores. These are simply values of

Table 3 The macroeconomic variables used in the analysis

Candidate economic variables

Trade balance (including gold)

Trade balance (excluding gold)

Exports

Imports

Rand gold price

Dollar gold price

World industrial material prices $(1980=100)$

World fibre prices $(1980=100)$

World metal prices $(1980=100)$

Exchange rate (R/S)

Financial Rand

Financial Rand discount

Government debt - total

Government debt - foreign

Inflation rate

Inflation differential (USA/SA)

Wholesale prices - consumer goods: all items

Wholesale prices - consumer goods: imported

Wholesale prices - consumer goods: S.A. produced

Prime overdraft rate of major commercial banks

Discount houses three-month B.A. Rate

R.S.A. long-dated stock rate

Real interest rate

Money supply: $\mathbf{M} 3$

Near money

Commercial banks, advances and discounts

Building societies change in mortgages outstanding

Dow Jones Index $(1925=100)$

USA industrial share prices deflated $(1980=100)$

Retail sales

Building plans passed: private sector

Buildings completed: private sector

Manufacturing production

Motor trade: total new vehicles sold

Retail sales the rotated factors at each point in time as calculated from equation (2.2) above. Two factor score vectors will be extracted in our analysis and will serve as the input for the Covariance Biplot.

\section{The data}

The share market data for the analysis consisted of the 26 non-gold JSE Actuarial Indices (see Appendix) for the months July 1978-July 1987. The month-to-month annualized returns of these indices were computed over the period August 1978-July 1987 for use in the analysis. As mentioned before, the use of indices of the universe of securities circumvents the problem of thin trading since the indices are constructed out of well-traded securities, and is consistent with the standard approach of using portfolios to eliminate the unsystematic risk.

As mentioned above, the gold indices were omitted because initial research indicated that there was only one macroeconomic factor which dominated the pricing of gold securities in an obvious way, viz. the gold price, and this effect tended to dominate the analysis. In fact, the rotated factor loadings of the initial analysis exhibited the same pattern as that established by Page (1986): the first (dominant) factor was composed entirely of gold and mining indices while the second factor was composed entirely of industrial indices.

The candidate macroeconomic variables are listed in Table 3. They represent a comprehensive range of monthly coinciding and leading indicators of the various sectors of the economy for the period July 1978-July 1987.

The data was extracted from the Standard Bank ECOCATS Econamic Data base.

\section{Results}

\section{Factor analysis}

The returns data for the 26 non-gold JSE indices were factor analysed for the period August 1979-July 1987.

Table 4 Correlation coefficients of the economic variables with the two factors

\begin{tabular}{llrr}
\hline Label & Economic variable & Factor 1 & Factor 2 \\
\hline A & Manufacturing production & 0,594 & -0.441 \\
B & Retail sales & 0.509 & -0.105 \\
C & Building plans passed (private) & 0.691 & 0,026 \\
D & Gold price & 0.733 & 0.240 \\
E & World metal prices & 0.652 & 0.402 \\
F & Industrial material prices & 0.600 & 0.339 \\
G & Allgold Index & 0,692 & 0.402 \\
H & Industrial index & 0,822 & 0.430 \\
I & Overall index & 0.715 & 0.543 \\
J & Change in mortgages outstanding & 0.287 & 0.653 \\
K & Dow Jones industrial average & 0.038 & 0.662 \\
L & Dow Jones share prices - deflated & -0.066 & 0,633 \\
M & Government debt - foreign & -0.699 & 0.050 \\
N & Three month B.A. Rate & -0.762 & -0.200 \\
O & Prime rate & -0.735 & -0.217 \\
\hline
\end{tabular}


Factor 1 can be seen to comprise predominantly industrial-orientated indices whereas Factor 2 comprises predominantly financial-orientated indices. Factor 1 and Factor 2 explained $55 \%$ and $31 \%$ of the total variation, respectively. The factor scores calculated directly from the loadings on the two factors comprise the input for the Covariance Biplot.

\section{The Covariance Biplot}

As discussed above the time series of the two security factors and the macroeconomic variables are plotted in the same two-dimensional space as a covariance biplot.

The column points (factors and macroeconomic variables) will be interpreted first and then the row points (different time points in months). The row points have been divided into five separate time periods for ease of interpretation.

Interpretation of Figure 1 (column points of the biplot, i.e. the factors and macroeconamic variables)

The two JSE Index factors are plotted as points 1 and 2 in Figure 1. These two column points plot at 900 to each other and at equal distances from the origin because they are orthogonal and have unit variance. Of the 35 candidate macroeconamic variables considered 12 were chosen for the analysis on the basis of the strength of correlation with either factor 1 or 2 . These variables with their correlations are listed in Table 4. Three composite JSE indices were included in the final analysis to demonstrate the relationship between the two factors and these broad indices. The macroeconamic variables and factors are plotted on the biplot as points $A$ to $O$.

Points $A, B$, and $C$ are the index of manufacturing production, total retail sales, and private sector building plans passed, respectively, and each are representive indicators of coinciding economic activity. These variables are all positively correlated with factor one which implies that the forces driving the first factor are closely linked to current economic activity.

Points D, E, and F represent the gold price, an index of world metal prices, and an index of industrial material prices, respectively. These variables are positively correlated with the first factor. The gold price is most highly correlated with the first factor with a correlation of 0,733 . Thus, the first factor is closely linked to world metal prices, especially the gold price. This points to the fact that economic activity in South Africa is to a large degree driven by the levels of gold/metal prices through their direct effect on the mining sector and the various filter-through effects on the rest of the economy.

Point $J$ is the change in the number of mortgages outstanding which is positively correlated with the second factor. Thus the second factor reflects to some

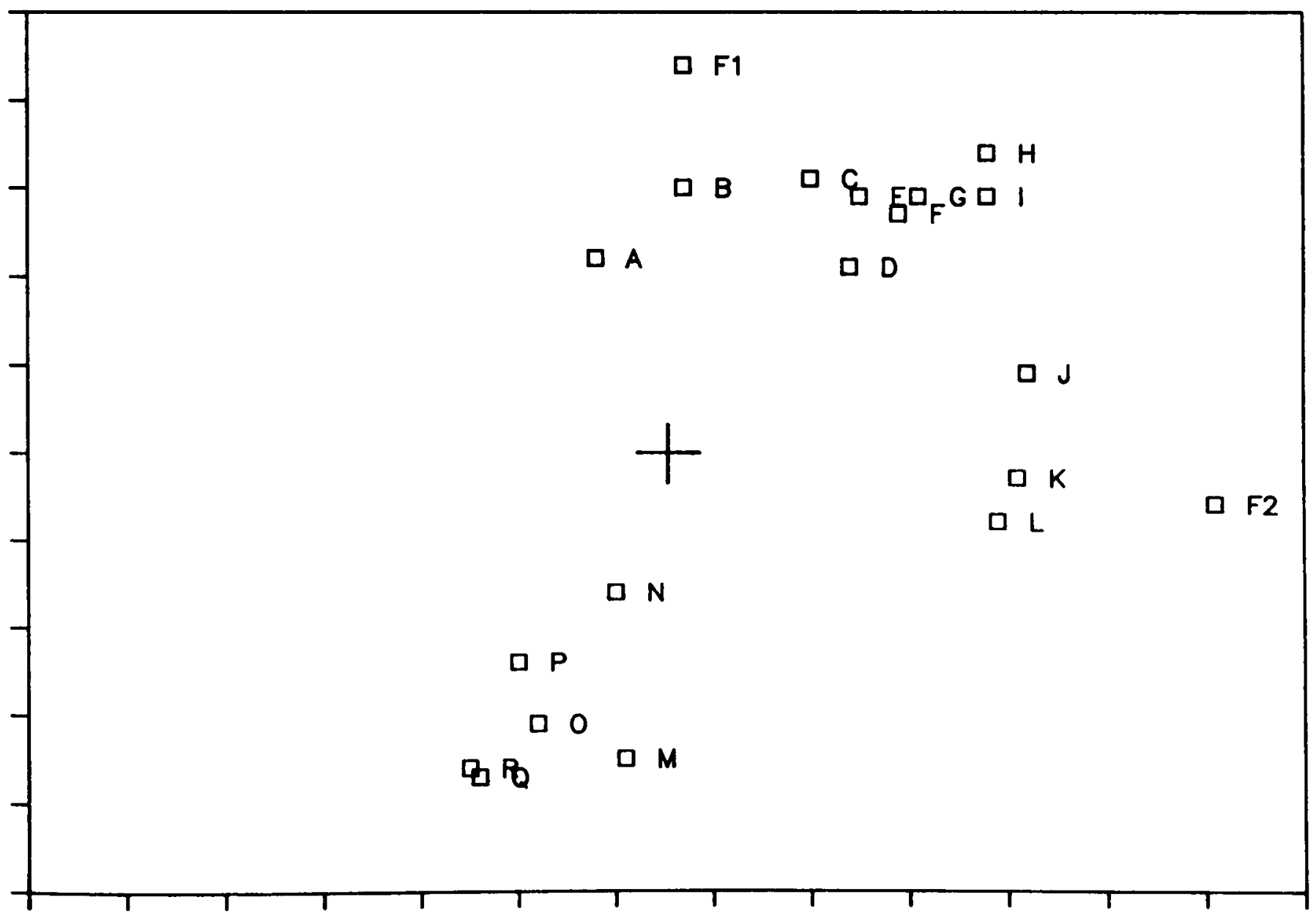

Figure 1 Column points and economic variables 
extent the buoyancy of the local housing market with its associated benefits for financiers (banks, etc.) on the one hand and building and construction on the other. This is reflected in the composition of factor 2 .

Points $K$ and $L$ are the Dow Jones Industrial Average and Index of the deflated share prices in the Dow Jones Average, respectively, which are positively correlated with factor two. Thus, the second factor reflects the influence of foreign markets (as proxied by the Dow Jones) on movements in local securities.

Point $M$ represents Foreign Government Debt (enumerated in Rands) which is inversely correlated with the first factor and uncorrelated with the second factor. The inverse correlation with the first factor can be attributed to the exchange rate rather than the net amount of rand debt since the level of debt in dollar terms declined slightly over the period of analysis.

Points $\mathrm{N}$ and 0 represent the Prime Rate and threemonth B.A. Rate respectively which are inversely correlated with the first factor and weakly related to the second factor. Thus rising interest rates, which choke off consumer confidence and expenditure, are generally associated with a weakening first factor, and thus a weak industrial market.

Points $G, H$, and I represent the Gold Index, the
Industrial Index, and the Overall Index, respectively, which are positively correlated with both factor 1 and factor 2. The two factors have been constructed to explain the maximum proportion of the variability of the original set of indices and thus the factors should represent the broad movements of the market. The positive correlation between the three composite indices and the two factors establishes the character of the two factors as broad indices embracing a large percentage of market movement.

In conclusion, the first factor represents the state of the industrial market and hence economic activity and manufacturing profitability in South Africa. It is highly influenced by the gold price and world mineral prices and negatively influenced by interest rates. The second factor is closely related to the financial sector and is driven to a large extent by the state of overseas economic activity and hence stockmarkets (as represented by the Dow Jones Index). In addition, buoyant activity in the local property market is a driving force for Factor 2.

\section{Row (time) point analyses (Figures 2-8)}

In order to consider the moving relationship between the JSE and the macroeconomic variables it is of considerable value to consider the row (time) points.

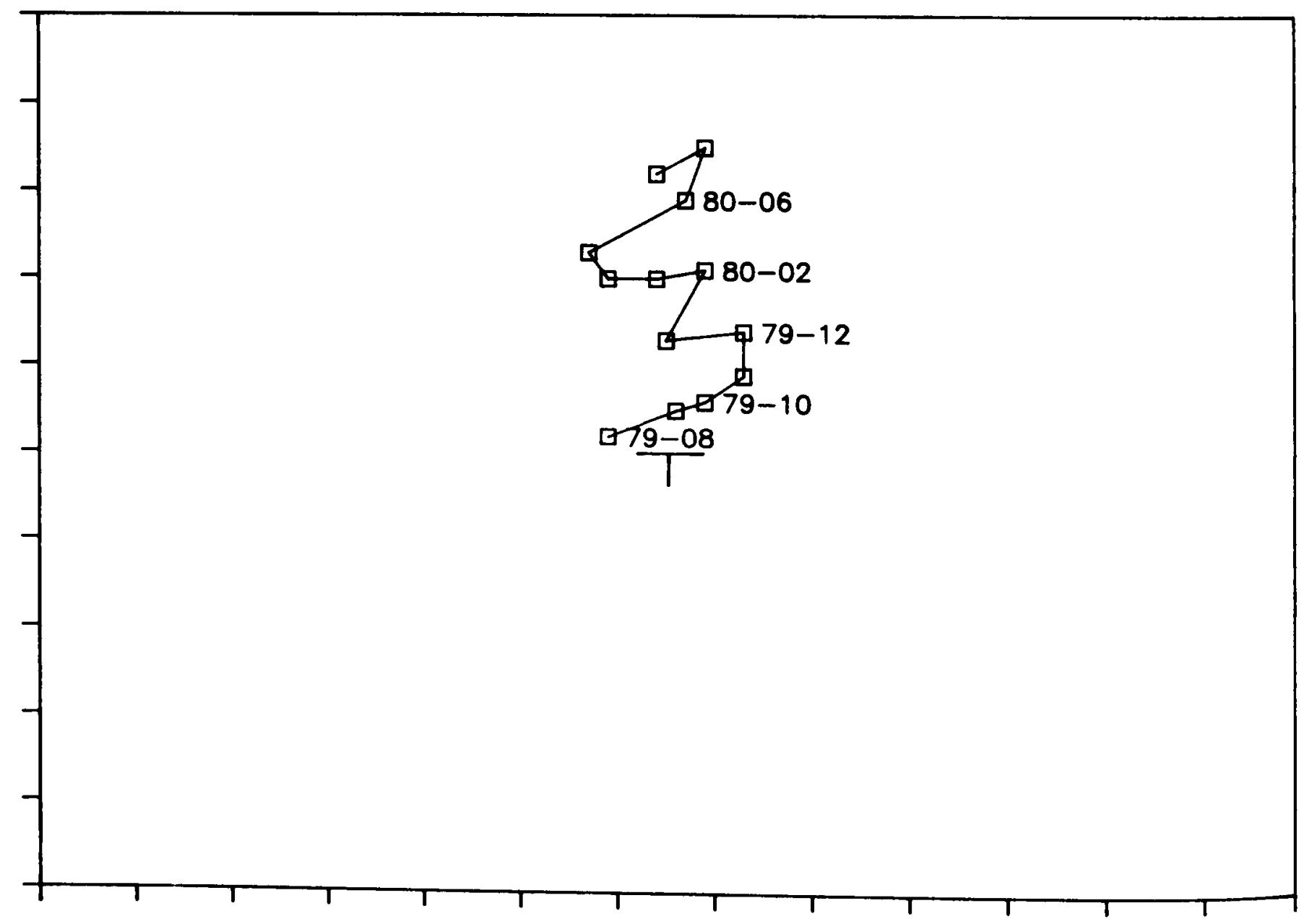

Figure 2 Time points: $1979.08-1980.08$ 
The row points represent 96 monthly observations for the eight years over which the analysis has been conducted. In order to aid visual interpretation, the eight-year period has been subdivided into five subperiods.

Period 1: 1979.08-1980.08 (Figure 2). Over this period the first factor moved up sharply (the row points move into the half-plane formed by the first factor) but the second factor demonstrated no real change in relative strength. This implies that the indices representing Factor 1 (primarily industrials) moved up sharply over this period relative to their average over the entire eightyear period but that those representing Factor 2 (primarily financials) do not demonstrate above-average performance over this period. The rise of the industrial sector was due to the massive increase in economic activity and expected profitability brought on by the sharp increase in the gold price over this period; the financial sector of the market was not expected to perform as dramatically and thus, by comparison, its performance was much weaker. Thus the first factor, driven by the high gold price and associated low interest rates, provided the main force for the strong market movement over this period.

Period 2: 1980.09-1981.11 (Figure 3). The sharp fall in the gold price over this period and the rise in interest rates put the brakes on the boom in expenditure.
Profitability started to decline and the impact on the market was absorbed predominantly via Factor 1 (industrials) which moved down sharply. Factor 2, which is influenced primarily by the state of foreign markets, was unaffected and moved sideways.

Period 3: 1981.12-1983.06 (Figure 4). Period 3 is dominated by movements in Factor 2 as metal prices play a (relatively) minor role in the market performance. The Dow Jones moved up strongly from June 1982 and the local property market continued to boom as local confidence remained high. From the middle of 1982 the financial sector of the market in particilar, strengthened sharply.

Period 4: 1983.07-1985.09 (Figure 5). Period 4 was a period of uncertainty, again dominated by the second factor. The market slid down until April 1985, particularly in the case of Factor 3 (the financially orientated sector of the market), following the sluggish performance of the Dow Jones. After April 1985 the market started to improve primarily, it appears, because of a rising Dow Jones.

Period 5: 1985.10-1987.07 (Figure 6). Period 5 is dominated by a rise in the first factor as the gold price rose steadily from $\$ 300$ to the high $\$ 400$ 's. Interest rates were low and economic activity gradually picked up from a low base as the economy began to shrug off the effects of the political instability of 1985-86. Local confidence,

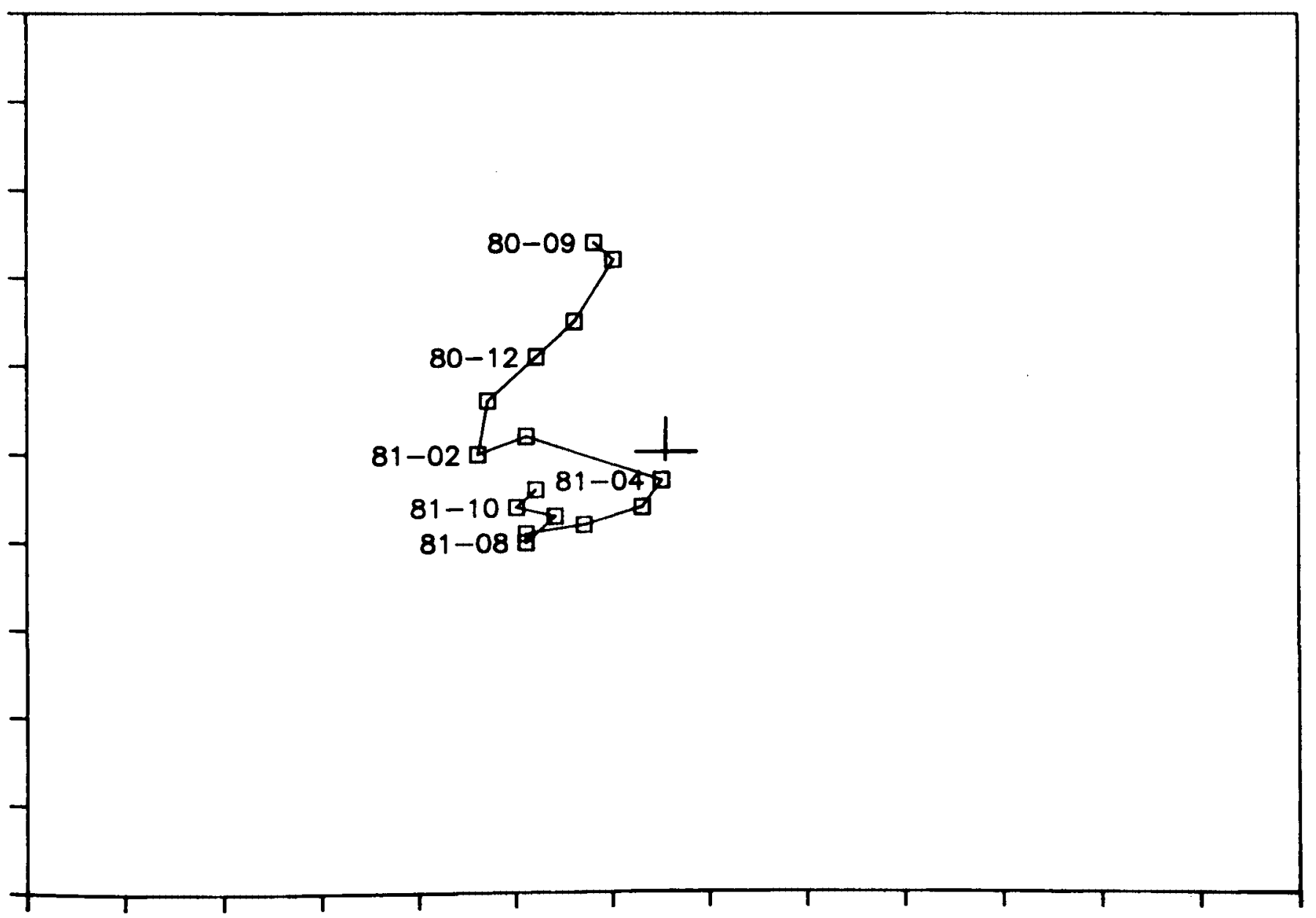

Figure 3 Time points: $1980.09-1981.11$ 


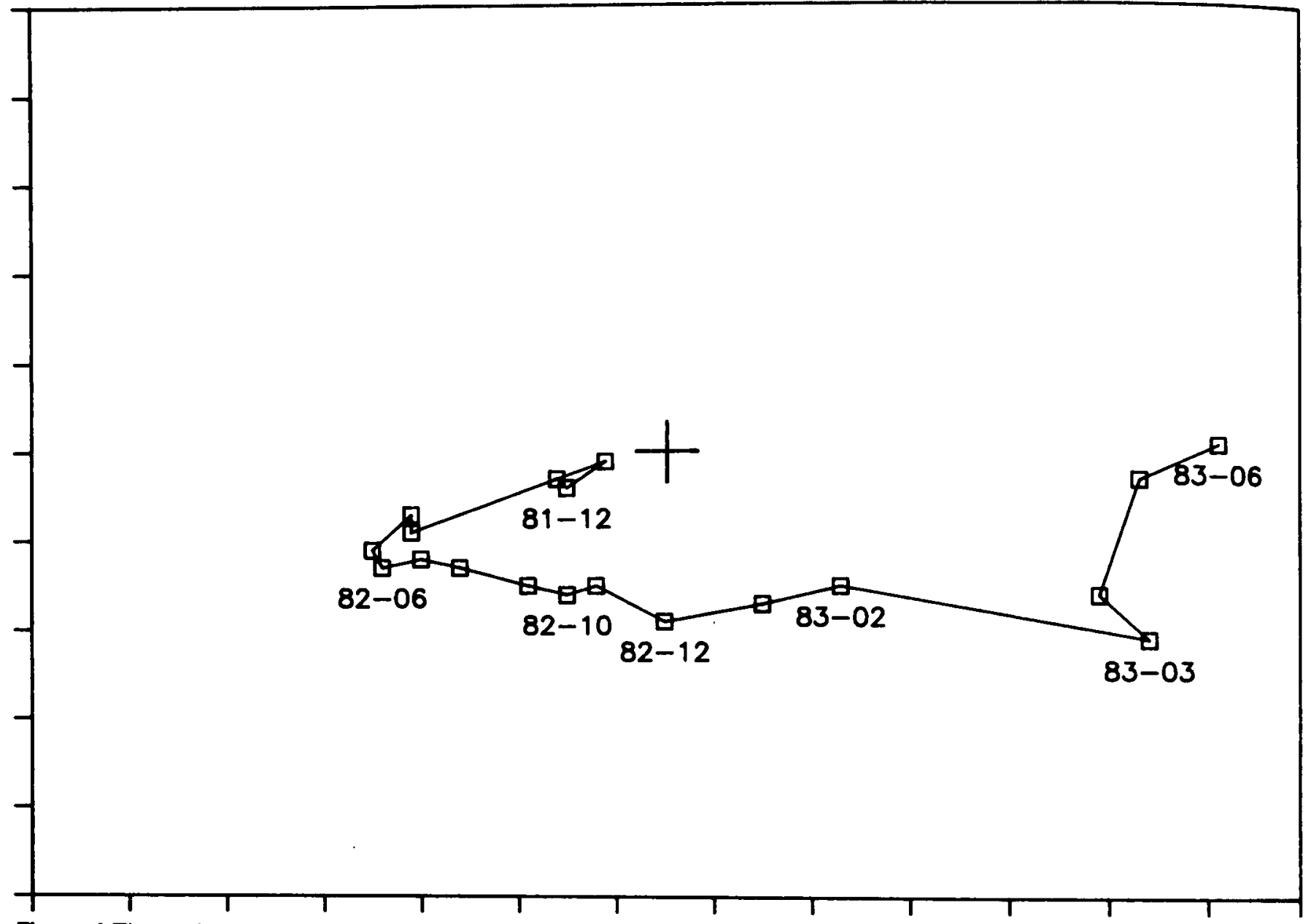

Figure 4 Time points: $1981.12-1983.06$

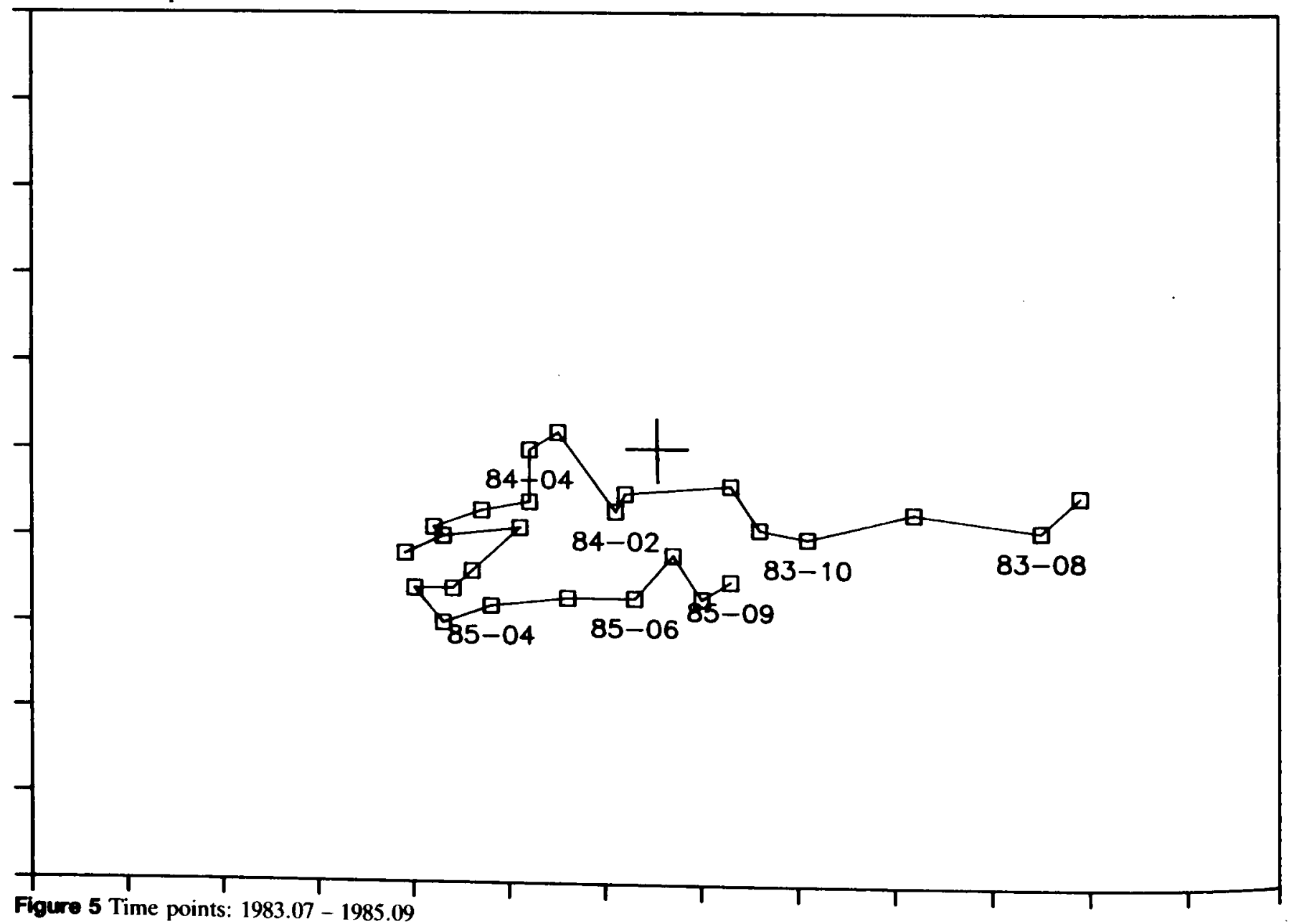




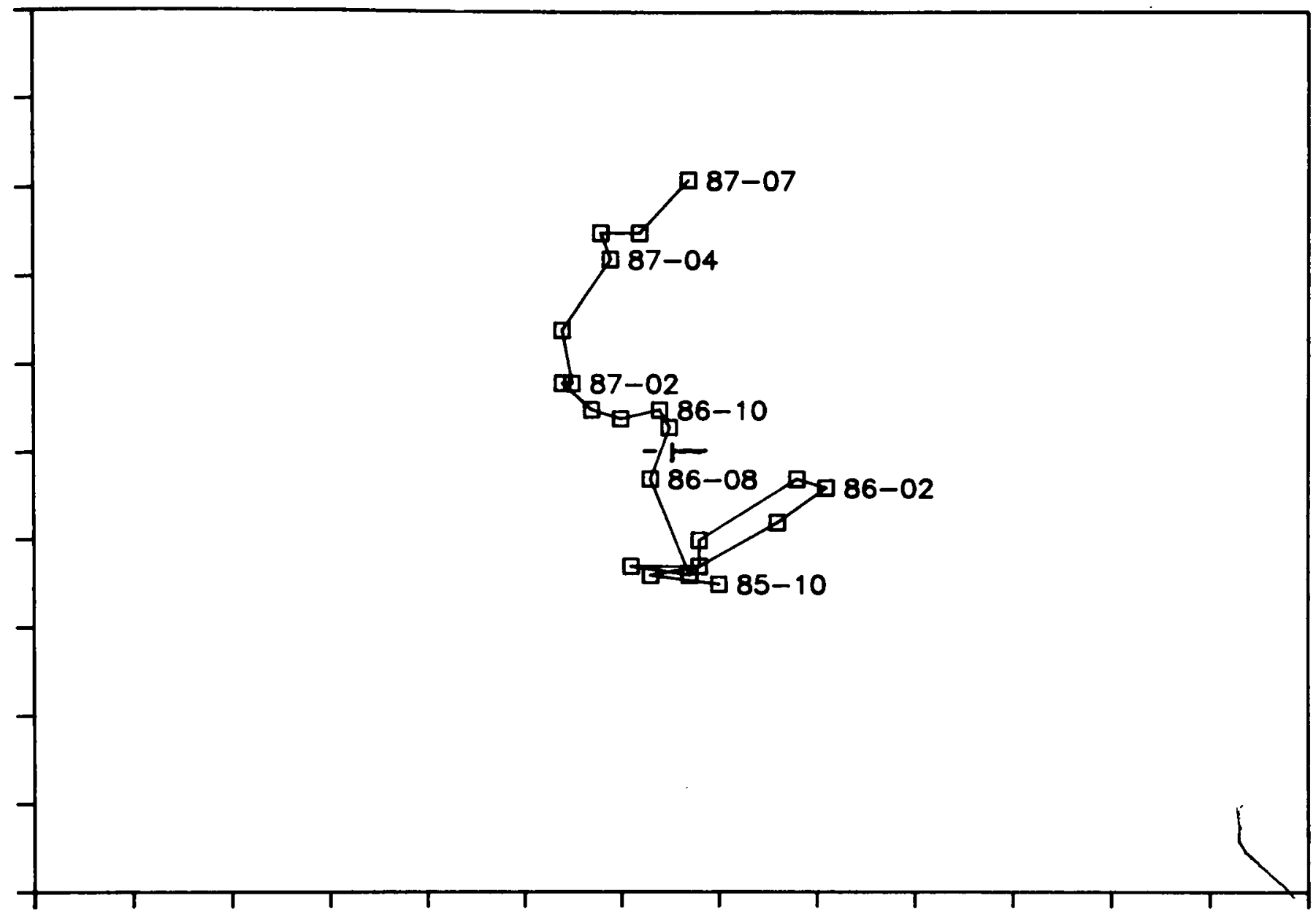

Figure 6 Time points: $1985.10-1987.07$

as reflected in the property market, was still low, however, and this exerted a negative influence on Factor 2 , cancelling out the effects of the increasing price levels on overseas share markets.

\section{Conclusion}

The analysis above has allowed us to consider the performance of the JSE in three ways. Firstly, it has enabled us to identify the character of the two main factors comprising JSE security movement. Factor 1 is primarily an industrial type index and Factor 2 a financial type index. Secondly, it has allowed us to identify the economic forces that are driving these factors, namely gold and interest rates in the case of Factor 1 and foreign share markets and a local property effect (representing a proxy for local confidence) in the case of Factor 2. Thirdly, it has allowed us to break down the period into several subperiods of differing character. Each subperiod has been dominated by either Factor 1 or Factor 2 and this approach allows us to identify when the various sectors of the market (described by the factors) perform best and which economic factors are driving these market sectors over each subperiod.

\section{References}

Agmon, T. \& Lessard, D.R. (1977). Investor recognition of corporate international diversification. J. Finance, vol.32(4).

Banz, R.W. (1981). The relationship between return and market value of common stock. J. Fin. Econ., vol. 9, 3-18.

Barr, G.D.I. \& Affleck-Graves, J.F. (1987). The covariance biplot and stock market data: An alternartive relative strength chart. S. Afr. J. Bus. Manage., vol.18(1), 46-50.

Basu, S. (1977). Investment performance of common stocks in relation to their price/earnings ratio: $A$ test of the Efficient Market Hypothesis.

J. Finance, vol 32(3), 663-682.

Beenstock, M. \& Chan, K. (1988). Economic forces in the London Stock Market. Oxf. Bull. Econ. Stat., vol.48, 121-141.

Berry, M.A. \& McElroy, M.B. (1988). Sorting out risks using known APT factors. Fin. Anal. J., March-April 1988 , $29-42$.

Bradfield, D.J., Barr, G.D.I. \& Affleck-Graves, J.F. (1988). Asset pricing in small markets - the South African case. $S$. Afr. J. Bus. Manage., vol.19(1), 11-21.

Carter, K.J. (1984). Multivariate techniques applied to share prices. Unpublished Ph.D. Thesis, University of Cape Town.

Chen, N., Roll, R. \& Ross, S.A. (1986). Economic forces and the stock market. J. Bus., vol.59, $283-403$.

Cho, D.C. (1984). On testing the APT: Inter-battery factor analysis. J. Finance, vol.39(5). 
Conway, D.A. \& Reinganum, M.R. (1988). Stable factors in security ret"rns: identification using cross validation. $J$.

Bus. Econ. Stat., vol.6(1), 1-28.

Dhrymes. P.J., Friend, I. \& Gultekin, N.B. (1984). A critical reexamination of the evidence on the APT. J. Fin., vol.39(2). 323-350.

Dhrymes. P.J. Friend, I.\& Gultekin, M.N. (1985). New tests of the APT and their implications. J. Fin., vol.40(2), 659-675.

Farrel. J.L. (1975). Homogeneous stock groupings. Fin. Anal. J. vol.31(3), 50-62.

Gilbertson, B.P. \& Roux, F.J.P. (1977). The JSE as an efficient market. Invest. Anal. J.. No. 9. 21-27.

Greenacre. M.J. (1984). Theory and applications of correspondence analvsis. Academic Press.

Greenacre, M.J. \& Underhill. L.G. (1982). Scaling a data matrix in a low-dimensional Euclidean Space. In: Topics in applied multivariate analysis. (Ed.: D.M. Hawkins), 183-268. Cambridge: Cambridge University Press.

Gultekin, M.N. \& Gultekin, N.B. (1987). Stock return anomalies and the tests of the APT. J. Fin., vol.42(5), 1213-1224.

Harman, H.H. (1976). Modern factor analysis. (3rd Edition Revised). The University of Chicago Press.

Meyer, P.G. (1986). An examination using arbitrage pricing theory of factors influencing commodity returns. Unpublished Technical Report, Graduate School of Business. University of Cape Town, 1986.

Page, M.J. (1986). Empirical testing of the APT using data from the Johannesburg Stock Exchange. S. Afr. J. Bus. Manage., vol.17, 38-42.

Reinganum, M.R. (1981). Misspecification of capital asset pricing: empirical anomalies based on earnings yields and market values. J. Finan. Econ., vol.9, 19-46.

Roll,R. (1977). A critique of asset pricing theory's tests. $J$. Finan. Econ., vol.4, May 1977, 129-176.

Roll, R. \& Ross, S.A. (1980). An empirical investigation of the APT. J. Finance, vol.35, 1073-1103.
Roll, R. \& Ross, S.A. (1984). The APT approach to strategic portfolio management. Finan. Anal. J.. May-June 1984, 14-26.

Ross, S.A. (1976). The arbitrage theory of capital asset pricing. J. Econ. Theory, vol.13, 341-360.

Shanken J. (1982). The arbitrage pricing theory: is it testable? J. Finance, vol.37, 1129-1140.

\section{Appendix The 28 non-gold Actuarial Indices}

1. Coal
2. Diamonds
3. Banks and financial services
5. Investment Trusts
6. Property
7. Property Trusts
8. Industrial Holding
9. Beverages and Hotels
10. Building and Construction
11. Chemicsls and Oils
12. Clothing, Footwear and Textiles
13. Electronics, Etc.
14. Engineering
15. Fishing
16. Food
17. Furniture and Household
18. Motor
19. Paper and Packaging
20. Pharmaceutical and Medical
21. Printing and Publishing
22. Steel and Allied
23. Retailers and Wholesales
24. Sugar
25. Tobacco and Match
26. Transport

